\title{
S100Z wt Allele
}

National Cancer Institute

\section{Source}

National Cancer Institute. S100Z wt Allele. NCI Thesaurus. Code C113559.

Human S100Z wild-type allele is located in the vicinity of $5 q 13.3$ and is approximately 72 $\mathrm{kb}$ in length. This allele, which encodes protein $\mathrm{S} 100-\mathrm{Z}$, is involved in calcium ion binding. Mutations in this gene are associated with ulcerative colitis. 